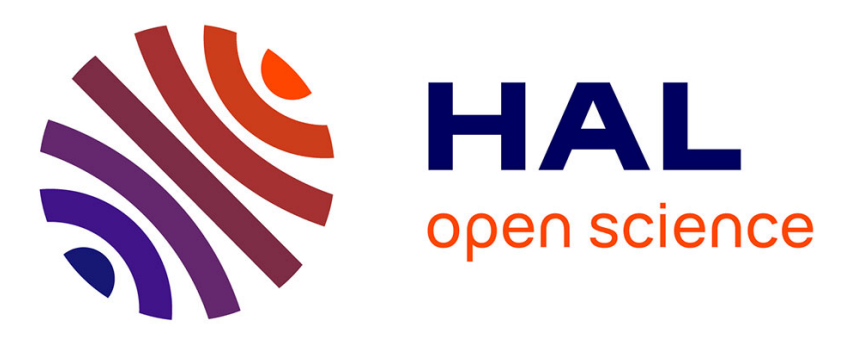

\title{
Triple-Decker Sandwich Complexes of Tungsten with Planar and Puckered Middle Decks
}

Ranjit Bag, Rini Prakash, Suvam Saha, Thierry Roisnel, Sundargopal Ghosh

\section{To cite this version:}

Ranjit Bag, Rini Prakash, Suvam Saha, Thierry Roisnel, Sundargopal Ghosh. Triple-Decker Sandwich Complexes of Tungsten with Planar and Puckered Middle Decks. Inorganic Chemistry, 2021, 60 (6), pp.3524-3528. 10.1021/acs.inorgchem.0c03411 . hal-03193279

\section{HAL Id: hal-03193279 \\ https://hal.science/hal-03193279}

Submitted on 18 Jan 2022

HAL is a multi-disciplinary open access archive for the deposit and dissemination of scientific research documents, whether they are published or not. The documents may come from teaching and research institutions in France or abroad, or from public or private research centers.
L'archive ouverte pluridisciplinaire HAL, est destinée au dépôt et à la diffusion de documents scientifiques de niveau recherche, publiés ou non, émanant des établissements d'enseignement et de recherche français ou étrangers, des laboratoires publics ou privés. 


\title{
Triple-Decker Sandwich Complexes of Tungsten with Planar and Puckered Middle-Deck
}

\author{
Ranjit Bag, † Rini Prakash, ${ }^{\dagger}$ Suvam Saha, ${ }^{\dagger}$ Thierry Roisnel, ${ }^{\ddagger}$ and Sundargopal Ghosh*, ${ }^{*}$ \\ †Department of Chemistry, Indian Institute of Technology Madras, Chennai 600036, India. \\ ‡Université de Rennes, CNRS, Institut des Sciences Chimiques de Rennes, UMR 6226, F-35000 Rennes, France \\ KEYWORDS: triple-decker, boron, tungsten, cobalt, sandwich complex
}

\section{Supporting Information Placeholder}

\begin{abstract}
Triple-decker complex of tungsten $\left[\left(\mathrm{Cp}^{*} \mathrm{~W}\right)_{2}\{\mu\right.$ $\left.\left.\eta^{6}: \eta^{6}-\mathrm{B}_{4} \mathrm{H}_{4} \mathrm{Co}_{2}(\mathrm{CO})_{5}\right\}(\mathrm{H})_{2}\right], \mathbf{1}\left(\mathrm{Cp}^{*}=\eta^{5}-\mathrm{C}_{5} \mathrm{Me}_{5}\right)$ with a planar middle-deck has been isolated by the thermolysis of an in situ formed intermediate from the reaction of $\mathrm{Cp}^{*} \mathrm{WCl}_{4}$ and $\mathrm{LiBH}_{4}$, with $\mathrm{Co}_{2}(\mathrm{CO})_{8}$. In addition, we have also isolated another triple-decker complex $\left[\left(\mathrm{Cp}^{*} \mathrm{~W}\right)_{2}\left\{\mu-\eta^{6}: \eta^{6}-\mathrm{B}_{5} \mathrm{H}_{5} \mathrm{Fe}(\mathrm{CO})_{3}\right\}(\mathrm{H})_{2}\right], 4$ having a puckered central ring, from a similar reaction with $\mathrm{Fe}_{2}$ (CO). . Clusters $\mathbf{1}$ and $\mathbf{4}$ are unprecedented examples of triple-decker complex having 24-valence electron with bridging hydrogens. Density-functional theory (DFT) calculations account for their stability and structural variation.
\end{abstract}

Ferrocene ${ }^{1}$ was a landmark discovery in the field of organometallic chemistry. Ever since, the quest for new sandwich complexes has been an integral part of this field which in turn resulted in the systematic growth of many multiple-decker complexes of various transition metals with different ring systems. $^{2-4}$ Triple-decker complexes are one of the major constituents among them, where two metals are sandwiched between three rings. ${ }^{5-7}$ Although the first triple-decker complex, $\left(\mathrm{Ni}_{2} \mathrm{Cp}_{3}\right)^{+}\left(\mathrm{Cp}=\eta^{5}-\mathrm{C}_{5} \mathrm{H}_{5}\right)$ was identified by Werner and Slazer in 1972,8 the first air stable and neutral triple-decker, $\left[(\mathrm{CoCp})_{2} \mathrm{RC}_{2} \mathrm{~B}_{3} \mathrm{H}_{4}\right](\mathrm{R}=\mathrm{H} / \mathrm{Me})$ was reported by Grimes. ${ }^{9}$ In addition to the geometrical relevance, sandwich complexes are also known for their unique physical properties, for example, ferrocene and its derivatives. They have been employed in many catalytic reactions, electrochemistry, medicine and even as a fuel additive. ${ }^{10,11}$ Multiple-decker complexes also exhibit distinctive magnetic and electrical properties and are considered as potential materials in molecular electronics. ${ }^{12,13}$
Besides the well-developed homoleptic triple-decker complexes, many examples of heteroleptic sandwich tripledeckers are known, where different ring systems are present.5-7 Among them, planar middle ring comprising single elements such as boron, phosphorus, arsenic etc. ${ }^{14}$ received significant notice. The first structurally characterized compound containing planar boron ring is $\left[\left(\mathrm{Cp}^{*} \mathrm{Re}\right)_{2}\left\{\mu-\eta^{6}: \eta^{6}\right.\right.$ $\left.\left.\mathrm{B}_{6} \mathrm{H}_{4} \mathrm{Cl}_{2}\right\}\right], 15$ in which a $\left\{\mathrm{B}_{6} \mathrm{H}_{4} \mathrm{Cl}_{2}\right\}$ ring makes a perfect planar hexagon. In addition, a few other triple-decker complexes with borane/heteroborane middle-deck have been synthesized and structurally characterized (Chart 1).16-20 The heteroatoms typically range from transition metals to other main group elements or sometimes it can be the combination of both. Although transition metal incorporated rings are highly desirable, they are rare. ${ }^{17-20}$ Thus, the synthesis of such type complexes became of interest.

Chart 1. Triple-decker complexes comprising boron in planar middle deck

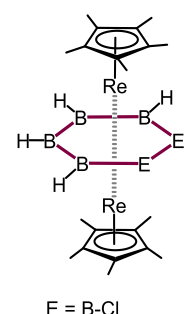

$\mathrm{E}-\mathrm{E}=\mathrm{Co}_{2}(\mathrm{CO})_{5}$

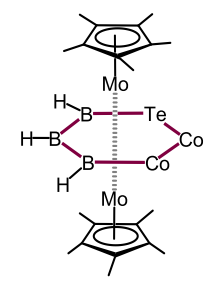

$\mathrm{Co}-\mathrm{Co}=\mathrm{Co}_{2}(\mathrm{CO})_{5}$

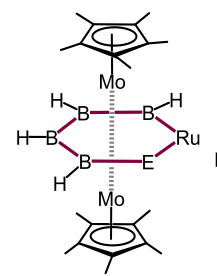

$\mathrm{E}=\mathrm{S}, \mathrm{Se}$ or $\mathrm{Te}$ $\mathrm{Ru}=\mathrm{Ru}(\mathrm{CO})_{3}$

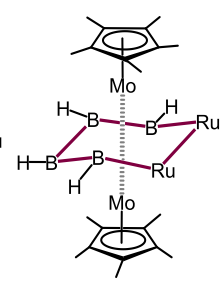

$\mathrm{Ru}=\mathrm{Ru}(\mathrm{CO})_{3}$
The synthesis of most of the triple-decker consisting a planar or puckered heteroborane central ring was accomplished by ring closure reactions of reactive metallaborane/ metallaheteroborane species.

Scheme 1. Syntheses of 1, 2, and 3
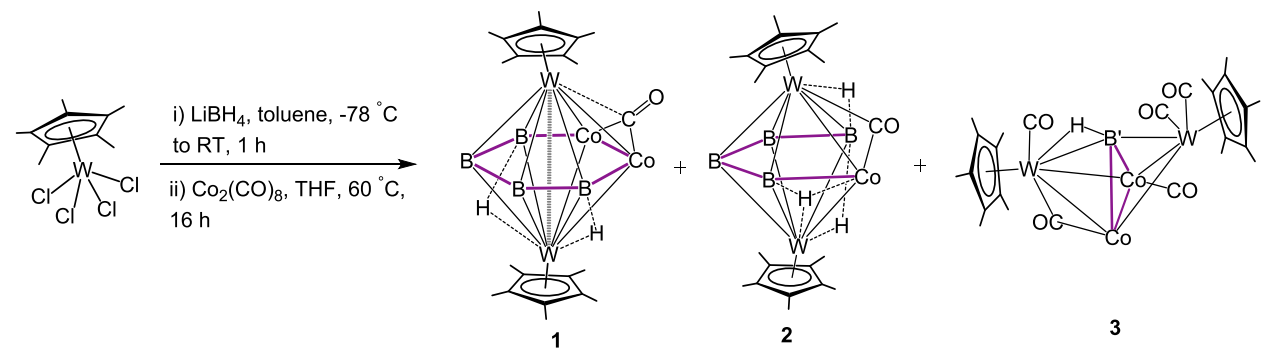

$\mathrm{Co}=\mathrm{Co}(\mathrm{CO})_{2} ; \mathrm{B}^{\prime}=\mathrm{BH} ; \mathrm{B}^{\prime}=\mathrm{B}$ 
Note that during our search for triple-decker complexes, we have isolated and structurally characterized few such complexes of molybdenum. For example, $\left[\left(\mathrm{Cp}^{*} \mathrm{Mo}\right)_{2}\left\{\mu-\eta^{6}: \eta^{6-}\right.\right.$ $\left.\left.\mathrm{B}_{3} \mathrm{H}_{3} \mathrm{TeCo}_{2}(\mathrm{CO})_{5}\right\}\right]^{18}$ and $\left[\left(\mathrm{Cp}^{*} \mathrm{Mo}\right)_{2}\left\{\mu-\eta^{6}: \eta^{6}-\mathrm{B}_{4} \mathrm{H}_{4} \mathrm{ERu}(\mathrm{CO})_{3}\right\}\right](\mathrm{E}$ $=\mathrm{S}$, Se or Te $)^{20}$ with a planar middle-deck and $\left[\left(\mathrm{Cp}^{*} \mathrm{Mo}\right)_{2}\{\mu\right.$ $\left.\left.\eta^{6}: \eta^{6}-\mathrm{B}_{4} \mathrm{H}_{4} \mathrm{Ru}_{2}(\mathrm{CO})_{6}\right\}\right]^{19}$ containing a puckered ring.

These results prompted us to investigate similar chemistry with tungsten. As a result, we have carried out the thermolysis of an in situ formed intermediate from the reaction of $\mathrm{Cp}^{*} \mathrm{WCl}_{4}$ and $\mathrm{LiBH}_{4}$, with $\mathrm{Co}_{2}(\mathrm{CO})_{8}$ that yielded brown 1 in $12 \%$ yield. The ESI-Mass spectrum of $\mathbf{1}$ indicated a molecular ion peak at $\mathrm{m} / z$ 859.1361. Two boron resonances at $\delta=91.8$ and 48.6 ppm were observed in ${ }^{11} \mathrm{~B}\left\{{ }^{1} \mathrm{H}\right\}$ NMR. The ${ }^{1} \mathrm{H}$ NMR spectrum reveals the presence of two $\mathrm{Cp}^{*}$ ligands at $\delta=2.19$ and 2.04 ppm. Besides the signals due to two B-H terminal protons, the ${ }^{1} \mathrm{H}$ NMR also shows an upfield chemical shift at $\delta=-10.47 \mathrm{ppm}$ which may be owing to the presence of bridging $\mathrm{W}-\mathrm{H}-\mathrm{B}$ protons. The presence of $\mathrm{CO}$ ligands was confirmed by IR spectroscopy.

A single crystal X-ray diffraction analysis was performed on a suitable crystal obtained from a solution of $\mathbf{1}$ in hexane and $\mathrm{CH}_{2} \mathrm{Cl}_{2}$ solution at $-2{ }^{\circ} \mathrm{C}$ for an unambiguous structural characterization. The solid state X-ray structure of 1 showed a ditungsten triple-decker sandwich complex where the hexagonal planar $\left[\mathrm{B}_{4} \mathrm{H}_{4} \mathrm{Co}_{2}(\mathrm{CO})_{5}\right]$ middle-deck (sum of internal angles $719.84^{\circ}$ ) is sandwiched between two $\left\{\mathrm{Cp}^{*} \mathrm{~W}\right\}$ fragments (Figure 1). The orientation of four terminal CO ligands of the $\mathrm{Co}_{2}(\mathrm{CO})_{5}$ fragment is in an eclipsed fashion which causes the bent of the $\mathrm{Cp}^{*}$ ligands and resulted the deviation of co-planarity of the three rings. In addition, the bridging CO ligand is inclined more towards one of the tungsten atoms. The $\mathrm{W}$-W bond length of $2.790 \AA$ is slightly shorter in comparison with other ditungstaboranes indicating a strong cross cluster bonding. ${ }^{21-22}$ The core geometry of $\mathbf{1}$ is analogues to that of $\left[\left(\mathrm{Cp}^{*} \mathrm{Re}\right)_{2}\left\{\mu-\eta^{6}: \eta^{6}-\mathrm{B}_{4} \mathrm{H}_{4} \mathrm{Co}_{2}(\mathrm{CO})_{5}\right\}\right]$ reported by Fehlner. ${ }^{17}$

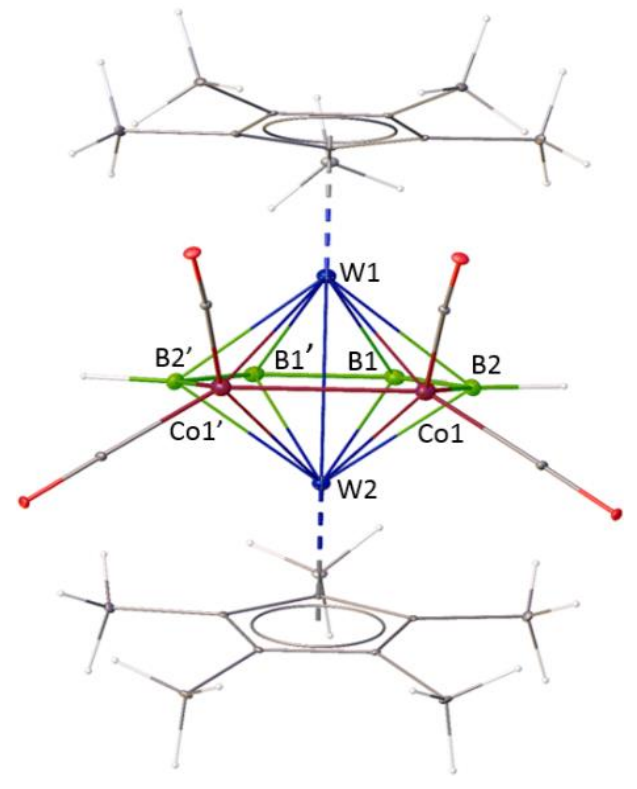

Figure 1. Molecular structure and labeling diagram for $\mathbf{1}$. Bridging hydrogens are not located and the $(\mu-\mathrm{CO})$ is not shown for clarity. Selected bond lengths $(\AA)$ : W1-W2 2.790, W1-Co1 2.6869(6), W2-B1 2.189(5), Co1-Co1' 2.5154(12), Co1-B2 2.125(5), B1-B2 1.708(7).
The presence of two bridging hydrogens in $\mathbf{1}$ was identified by ${ }^{1} \mathrm{H}$ NMR. However, they couldn't be located crystallographically. Hence to confirm their presence and position, the ${ }^{11} \mathrm{~B}\left\{{ }^{1} \mathrm{H}\right\}-{ }^{-1} \mathrm{H} H S Q \mathrm{C}$ experiment was performed that established a correlation between the bridging hydrogen and the boron resonance observed at $\delta=48.6 \mathrm{ppm}$. Also, the ${ }^{11} \mathrm{~B}$ NMR spectrum shows a lesser coupling constant $U_{\mathrm{B}-\mathrm{H}}=131$ $\mathrm{Hz}$ ) for this peak as compared to the peak at $\delta=91.8 \mathrm{ppm}\left(\mathrm{J}_{\mathrm{B}-\mathrm{H}}\right.$ $=155 \mathrm{~Hz}$ ). This spectroscopic data goes hand in hand with the theoretically calculated structure having two $\mu_{3}-\mathrm{H}$ connected to W-B-Co face, shown in Scheme 1 and Figure S31. The two bridging hydrogens are connected to one of the metals in $\mathbf{1}$, making their environment entirely different. The difference is also seen in the variation in natural charge around the metals from natural population analysis (Table S4). Thus, cluster $\mathbf{1}$ is a 24-ve triple-decker complex with formula [(Cp*W $)_{2}\left\{\mu-\eta^{6}: \eta^{6}\right.$ $\left.\left.\mathrm{B}_{4} \mathrm{H}_{4} \mathrm{Co}_{2}(\mathrm{CO})_{5}\right\}(\mathrm{H})_{2}\right]$. Hence, $\mathbf{1}$ can be identified as an unprecedented example of triple-decker complex comprising bridging hydrogens. In parallel, the geometry of $\mathbf{1}$ can also be viewed as an oblatocloso-hexagonal bipyramid with 6 sep, which is in agreement with (n-2) sep for such structural type, similar to that of reported triple-decker complexes. ${ }^{17-20}$

In addition to the formation of $\mathbf{1}$, the reaction also generated compounds 2 and 3 in 11\% and 14\% yields (Schemes 1 and $\mathrm{S} 1)$. The ${ }^{11} \mathrm{~B}\left\{{ }^{1} \mathrm{H}\right\}$ NMR spectrum of 2 shows four peaks at $\delta=$ 72.5, 53.8, 45.4 and $24.2 \mathrm{ppm}$. The ${ }^{1} \mathrm{H}$ NMR spectrum reveals the existence of one type of $\mathrm{Cp}^{*}$ ligand and two types of bridging hydrogen. The mass spectrometric data confirms the composition as $\mathrm{C}_{25} \mathrm{H}_{37} \mathrm{~B}_{4} \mathrm{O}_{5} \mathrm{~W}_{2} \mathrm{Co}$. The solid-state X-ray structural characterization along with the spectroscopic details establishes cluster 2 as trimetallic cluster, $\left[\left(\mathrm{Cp}^{*} \mathrm{~W}\right)_{2}(\mu-\right.$ $\left.\mathrm{H})_{2}\left(\mu_{3}-\mathrm{H}\right) \mathrm{B}_{4} \mathrm{H}_{4} \mathrm{Co}(\mathrm{CO})_{3}\right]$ (Figures S2 and S32). The core structure of $\mathbf{2}$ is analogous to the reported molybdaborane species, $\left[\left(\mathrm{Cp}^{*} \mathrm{Mo}\right)_{2} \mathrm{~B}_{4} \mathrm{H}_{4} \mathrm{~W}(\mathrm{CO})_{4}(\mu-\mathrm{H})_{2}\left(\mu_{3}-\mathrm{H}\right)_{2}\right], \quad\left[(\mathrm{Cp} * \mathrm{Mo})_{2} \mathrm{~B}_{4} \mathrm{H}_{4} \mathrm{~W}(\mathrm{CO})_{5}\right.$ $\left.(\mu-\mathrm{H})_{2}\right]^{21}$ and tungstaboranes, [(Cp*W $\left.)_{2} \mathrm{~B}_{4} \mathrm{H}_{8} \mathrm{M}(\mathrm{CO})_{4}\right],(\mathrm{M}=\mathrm{Cr}$, Mo and W).22 The 6-sep cluster 2 can be considered as an $o b$ latonido species obtained from an 8-vertex oblatocloso hexagonal bipyramid. Alternatively, it can also be viewed as a trigonal bipyramidal geometry with central $\left[\mathrm{W}_{2} \mathrm{~B}_{3}\right]$ unit, capped by $\left[\mathrm{Co}(\mathrm{CO})_{3}\right]$ and $\left\{\mathrm{BH}_{3}\right\}$ fragments at $\left[\mathrm{W}_{2} \mathrm{~B}\right]$ triangular faces. Compound $\mathbf{3}$ was also characterized by various NMR spectroscopic as well as by single-crystal X-ray diffraction technique that confirm it as heterometallic semi-interstitial boride (Figure S3). Note that due to low yields and higher sensitivity, the elemental analysis of the compounds couldnt be performed. The melting points of all the compounds show temperature above $300{ }^{\circ} \mathrm{C}$ (see supporting information, general procedures and instrumentation).

Although we do not have any clear evidence for the formation of complexes $\mathbf{1}$ and $\mathbf{2}$, it seems that they have been generated from the sequential metal carbonyl addition to tungstaborane intermediate, $\left[\left(\mathrm{Cp}^{*} \mathrm{~W}\right)_{2} \mathrm{~B}_{4} \mathrm{H}_{10}\right],{ }^{23} \mathbf{I}$ (Scheme S2). Further, we believe that the cobalt tetracarbonyl hydride, $\left[\mathrm{Co}(\mathrm{CO})_{4} \mathrm{H}\right]$ might be one of the byproducts in the reaction, which could not be identified due to its unstable and volatile nature.

The existence of $\mathbf{1}$ and earlier reported triple-decker [(Cp*Re) $\left.{ }_{2}\left\{\mu-\eta^{6}: \eta^{6}-\mathrm{B}_{4} \mathrm{H}_{4} \mathrm{Co}_{2}(\mathrm{CO})_{5}\right\}\right]$, (vide infra) apparently suggest that a combination of heavier transition metal with appropriate first row metal carbonyl fragments can lead to the synthesis of planar triple-decker species. Thus, with an objective to synthesize complex analogous to $\mathbf{1}$ by introducing $\mathrm{Fe}_{2}(\mathrm{CO})_{6}$ fragment in the middle-deck, we have carried out the similar reaction with $\mathrm{Fe}_{2}(\mathrm{CO})_{9}$. The reaction yielded unstable 
yellow compound 4 in poor yield (Scheme S3). The ${ }^{11} \mathrm{~B}\left\{{ }^{1} \mathrm{H}\right\}$ NMR spectrum showed three broad signals at $\delta=85.2,78.8$ and $38.4 \mathrm{ppm}$. The ${ }^{1} \mathrm{H}$ NMR spectrum displayed two $\mathrm{Cp}^{*}$ peaks (at $\delta=2.27$ and $2.04 \mathrm{ppm}$ ) along with a highly shielded upfield resonance at $\delta=-10.60 \mathrm{ppm}$ which may be due to the presence of $\mathrm{W}-\mathrm{H}$-B protons. The IR spectroscopy confirmed the existence of carbonyl ligands. The ESI-Mass spectrum analysis of 4 indicated a molecular ion peak at $m / z$ 840.1720.

To determine the structure of $\mathbf{4}$, a single crystal X-ray diffraction was performed. Though, the solid-state structure of 4 derived as triple-decker with $\left[\left(\mathrm{Cp}^{*} \mathrm{~W}\right)_{2}\left\{\mu-\eta^{6}: \eta^{6}-\mathrm{B}_{5} \mathrm{H}_{5} \mathrm{Fe}(\mathrm{CO})_{3}\right\}\right]$ core, the middle-deck shows a puckered ring with a mean deviation of $0.1065 \AA$ (Figure S5) and sum of internal angle of $712.20^{\circ}$. As shown in Figure 2, the puckered middle-deck is sandwiched between two $\left\{\mathrm{Cp}^{*} \mathrm{~W}\right\}$ fragments and contains one $\mathrm{Fe}(\mathrm{CO})_{3}$ fragment. The molecular structure shows that the presence of three CO ligands at Fe might be the reason behind the bending of $\mathrm{Cp}^{*}$ ligands in a disrotatory fashion. The $\mathrm{W}-\mathrm{W}$ bond length of 2.8121(4) Å is slightly longer than 1, while the average B-B bond distance of $1.72 \AA$ is comparable to other tungstaboranes. ${ }^{21-22}$

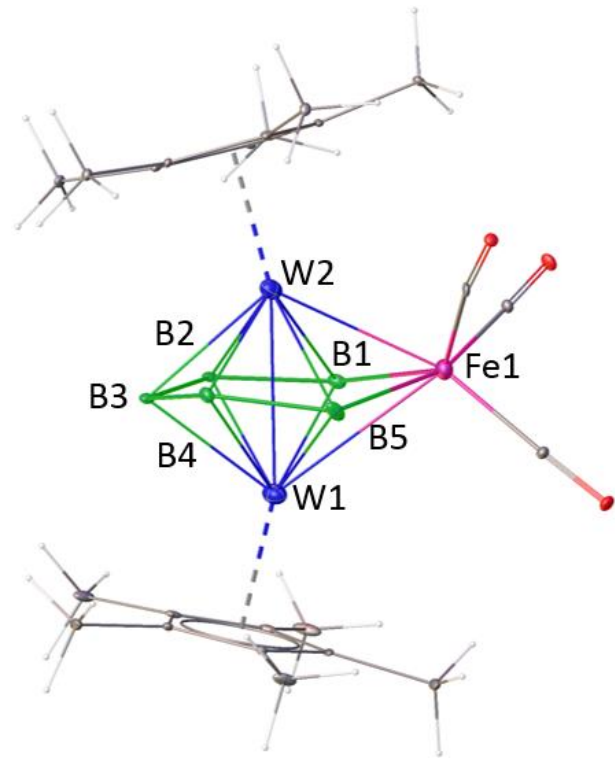

Figure 2. Molecular structure and labeling diagram for 4. Bridging hydrogens are not located. Bond distances $(\AA)$ : W1W2 2.8121(4), W1-Fe1 2.8594(10), B5-Fe1 2.278(10), B1-B2 $1.717(13)$.

The bridging hydrogens in $\mathbf{4}$ could not be located by X-ray crystallography and unfortunately, a solution state NMR studies using ${ }^{11} \mathrm{~B}-1 \mathrm{H}$ HSQC could not be performed due the poor yield and the sensitive nature of 4 . Nonetheless, a detailed DFT study enabled us to predict the plausible position of the bridging hydrogens. Although the geometry of 4' (Cp analogues of 4) optimized with two bridging hydrogens shows good agreement of the calculated and experimental ${ }^{11} \mathrm{~B}$ NMR chemical shift values (Figure S33 and Table S2), it doesn't support the existence of single bridging proton in the ${ }^{1} \mathrm{H}$ NMR spectrum. All of our attempts to optimize more symmetric structures were not successful. This discrepancy might be a possible indication of fluxionality of the bridging hydrogens present in molecule at solution phase.

The presence of bridging hydrogen in a closed triple-decker structure is very unusual. Indeed, among all the metallaborane/ metallaheteroborane based triple-decker complexes reported by Fehlner, us and others (Table S5), $\mathbf{1}$ and $\mathbf{4}$ are the only examples with bridging hydrogen. As a result, a detailed electronic structure analysis was performed to get an insight about the structure and bonding of $\mathbf{1}$ and $\mathbf{4}$. We compared the structures of 24-ve $\mathbf{1}^{\prime}$ and $\mathbf{4}^{\prime}$ (Cp analogues of $\mathbf{1}$ and 4) with the corresponding hypothetical 22-ve complexes II and III without bridging hydrogens. The structure of II is optimized with large imaginary frequency with slight distortion in the middle ring indicating non-existence of such molecule (Figure S34). On the other hand, although III was optimized without any negative frequency, the molecular orbital analysis suggests an unstable system with the HOMO-LUMO gap of 0.70 $\mathrm{eV}$. Hence, the presence of two bridging hydrogens stabilizes the molecules to a larger extent (Table S3) and the HOMOLUMO energy gap increases significantly for $\mathbf{1}^{\prime}$ and $\mathbf{4}^{\prime}$. Another point to note is that, even after having same valence electrons of 24, complexes $\mathbf{1}$ and $\mathbf{4}$ adopt planar and puckered ring structure respectively. In principle, the puckering of the central ring in triple-decker complexes is correlated with the orbital interaction of the metal with the ring. ${ }^{14 \mathrm{~b}}$ Thus, we believe this might be the case for $\mathbf{4}$ where the middle-deck has to undergo ring distortion to match the energies and symmetries of their orbitals with the metal fragment orbitals to get a better overlap. ${ }^{19}$

In spite of having different core structures for $\mathbf{1}^{\prime}$ and $\mathbf{4}^{\prime}$, the frontier molecular orbitals and their energy differences (ELumo-номо) are quite similar (Figure S29). The HOMOs of them show $\mathrm{W}$-W $\sigma$-bonding, while the LUMOs represent the $\mathrm{W}$-W $\delta$-bonding. Additionally, a larger HOMO-LUMO gap of $\sim 3.25 \mathrm{eV}$ for $\mathbf{1}^{\prime}$ and $\mathbf{4}^{\prime}$ is in accord with other stable 24-ve species.17-20 Comparison of molecular orbitals of $\mathbf{1}^{\prime}$ with $\left[(\mathrm{CpRe})_{2}\left\{\mu-\eta^{6}: \eta^{6}-\mathrm{B}_{4} \mathrm{H}_{4} \mathrm{Co}_{2}(\mathrm{CO})_{5}\right\}\right]$, IV represents a different bonding scenario. Although the LUMO of IV is comparatively similar to that of $\mathbf{1}^{\prime}$, the HOMO of IV shows the bonding interaction of $\mathrm{Co}_{2}(\mathrm{CO})_{5}$ fragment with $\mathrm{Re}$ and adjacent boron atoms (Figure S30). Instead, the Re-Re $\sigma$-bonding interaction is visible at a more stabilized HOMO-3 and HOMO-4 orbitals. The M$\mathrm{M} \sigma$-antibonding orbital stay higher and unoccupied at LUMO +3 for both $\mathbf{1}^{\prime}$ and IV and at LUMO +6 for $\mathbf{4}^{\prime}$ that indicate a strong M-M interaction (Figures S29 and S30). A higher Wiberg bond index of 0.76 and 0.70 for $\mathrm{M}-\mathrm{M}$ bond in $\mathbf{1}^{\prime}$ and $\mathbf{4}^{\prime}$ respectively also suggest a stronger interaction, which is consistent with a single bond order. Indeed, the presence of short $\mathrm{M}-\mathrm{M}$ bond in these molecules is the major factor for stabilizing the structure in a lower valence electron count of $24 .^{20}$

In summary, this work described the isolation and structural characterization of multi-metallic 24-ve triple-decker sandwich complexes of tungsten having a planar or a puckered middle-deck. They are novel examples of tripledeckers bearing bridging hydrogens. Theoretical studies indicate higher stabilization of the complexes due to the presence of two bridging hydrogens. Interestingly, the molecular orbital analysis further shows a similar bonding situation and thermodynamic stability for both the complexes in spite of their structural difference.

\section{ASSOCIATED CONTENT}

\section{Supporting Information}

Experimental procedures, additional experimental data, crystallographic data and computational data for compounds 1-4. The Supporting Information is available free of charge at http://pubs.acs.org.

\section{AUTHOR INFORMATION}




\section{Corresponding Author}

*E-mail: sghosh@iitm.ac.in

\section{Author Contributions}

Notes

The authors declare no competing financial interests.

\section{ACKNOWLEDGMENT}

This work was supported by SERB, New Delhi, India, project no. CRG/2019/001280. R.B. and R.P. thank IIT Madras and S.S. thank INSPIRE for the research fellowships.

\section{REFERENCES}

(1) Kealy, T. J.; Pauson, P. L. A New Type of Organo-Iron Compound. Nature 1951, 168, 1039-1040.

(2) Neto, A. F.; Pelegrino, A. C.; Darin, V. A. Ferrocene: 50 Years of Transition Metal Organometallic Chemistry-From Organic and Inorganic to Supramolecular Chemistry, ChemInform, 2004, p. 35.

(3) (a) Werner, H. New Varieties of Sandwich Complexes. Angew. Chem. Int. Ed. Engl. 1977, 16, 1-9. (b) Siebert, W. 2,3-Dihydro1,3-diborole-Metal Complexes with Activated C-H Bonds: Building Blocks for Multilayered Sandwich Compounds. Angew. Chem. Int. Ed. Engl. 1985, 24, 943-958. (c) Chivers, T.; Manners, I. Inorganic rings and polymers of the p-block elements: from fundamentals to applications, RSC Publishing, Cambridge, 2009.

(4) (a) Haaland, A. Molecular structure and bonding in the 3d metallocenes. Acc. Chem. Res. 1979, 12, 415-422. (b) Jemmis, E. D.; Reddy, A. C. Electronic structure of triple decker compounds with $\mathrm{P}_{5}, \mathrm{P}_{6}, \mathrm{As}_{5}$ and $\mathrm{C}_{\mathrm{n}} \mathrm{H}_{\mathrm{n}}$ as middle rings. Organometallics, 1988, 7, 1561-1564. (c) Ghag, S. K.; Tarlton, M. L.; Henle, E. A.; Ochoa, E. M.; Watson, A. W.; Zakharov, L. N.; Watson, E. J. Synthesis and Structures of Triple-Decker Complexes with a Bridging Tetramethylcyclopentadienyl Ligand. Organometallics 2013, 32, 1851-1857.

(5) (a) Grimes, R. N., Carboranes 3rd ed.; Elsevier: Amsterdam, 2016. (b) Siebert, W.; Edwin, J.; Bochmann, M. Paramagnetische Tripeldeckersandwich-Komplexe. Angew. Chem. 1978, 90, 917918. (c) Grimes, R. N. Boron-carbon ring ligands in organometallic synthesis. Chem. Rev. 1992, 92, 251-268. (d) Saxena, A. K.; Hosmane, N. S. Recent advances in the chemistry of carborane metal complexes incorporating d- and f-block elements. Chem. Rev. 1993, 93, 1081-1124.

(6) (a) Lauher, J. W.; Elian, M.; Summerville, R. H.; Hoffmann, R. Triple-decker sandwiches. J. Am. Chem. Soc. 1976, 98, 3219-3224. (b) Beck, V.; O'Hare, D. Triple-decker transition metal complexes bridged by a single carbocyclic ring. J. Organomet. Chem. 2004, 689, 3920-3938. (c) Loginov, D. A.; Muratov, D. V.; Kudinov, A. R. Triple-decker complexes with a central borole ligand $\mathrm{C}_{4} \mathrm{H}_{4} \mathrm{BR}$. Russ. Chem. Bull. 2008, 57, 1-7. (d) Forward, J. M.; Mingos, D. M. P.; Siebert, W.; Hauss, J.; Powell, H. R. Synthesis and characterization of novel metallocarborane triple-decker complexes. J. Chem. Soc., Dalton Trans. 1993, 1783-1788.

(7) (a) Pérez, V.; Barnes S. S.; Fontaine, F.-G. Generation of Group VI Piano-Stool and Triple-Decker Complexes from [(IMes $)_{2} \mathrm{PtH}(\mathrm{Cl}$-boratabenzene)] Species. Eur. J. Inorg. Chem. 2014, 14, 5698-5702. (b) Madl, E.; Peresypkina, E.; Timoshkin, A. Y.; Scheer, M. Triple-decker sandwich complexes with a bent cyclo- $\mathrm{P}_{5}$ middle-deck. Chem. Commun. 2016, 52, 12298-12301. (c) Muratov, D. V.; Romanov, A. S.; Corsini, M.; Kudinov, A. R.; de Biani, F. F.; Siebert, W. The First Triple-Decker Complex with a Carbenium Center, $\left[\mathrm{CpCo}\left(\mu-\mathrm{C}_{3} \mathrm{~B}_{2} \mathrm{Me}_{5}\right) \mathrm{RuC}_{5} \mathrm{Me}_{4} \mathrm{CH}_{2}\right]^{+}$: Synthesis, Reactivity, XRay Structure, and Bonding. Chem. Eur. J. 2017, 23, 11935-11944.

(8) (a) Werner, H.; Salzer, A. Die Synthese Eines Ersten Doppel-Sandwich-Komplexes: Das Dinickeltricyclopentadienyl-Kation.
Synth. React. Inorg. Met.-Org. Chem. 1972, 2, 239-248. (b) Salzer, A.; Werner, H. A New Route to Triple-Decker Sandwich Compounds. Angew. Chem., Int. Ed. Engl. 1972, 11, 930-932. (c) Schumacher, E.; Taubenest, R. «Tripeldecker-Sandwiches» aus Ferrocen und Nickelocen. Helv. Chim. Acta 1964, 47, 1525-1529.

(9) (a) Beer, D. C.; Miller, V. R.; Sneddon, L. G.; Grimes, R. N.; Mathew. M.; Palenik, G. J. Triple-decked sandwich compounds. Planar $\mathrm{C}_{2} \mathrm{~B}_{3} \mathrm{H}_{5}^{4-}$ cyclocarborane ligands analogous to $\mathrm{C}_{5} \mathrm{H}_{5}$. J. Am. Chem. Soc. 1973, 95, 3046-3048. (b) Grimes, R. N. Structure and stereochemistry in metalloboron cage compounds. Acc. Chem. Res. 1978, 11, 420-427. (c) Grimes, R. N. Metal sandwich complexes of cyclic planar and pyramidal ligands containing boron. Coord. Chem. Rev. 1979, 28, 47-96.

(10) (a) Togni, A.; Hayashi, T. Eds.; Ferrocenes, VCH, Weinheim, 1995. (b) Heinze, K.; Lang, H. Ferrocene-Beauty and Function. Organometallics 2013, 32, 5623- 5625 .

(11) a) Melendez, E. Metallocenes as target specific drugs for cancer treatment. Inorg. Chim. Acta 2012, 393, 36-52. (b) Colacot, T. J.; Hosmane, N. S. Organometallic Sandwich Compounds in Homogeneous Catalysis: An Overview. Z. anorg. Allg. Chem. 2005, 631, 2659-2668.

(12) (a) Siebert, W. From sandwich and triple-decker to organometallic polymers. Russ. Chem. Rev. 1991, 60, 784-791. (b) Astruc, D. From Organotransition-Metal Chemistry toward Molecular Electronics: Electronic Communication between Ligand-Bridged Metals. Acc. Chem. Res. 1997, 30, 383-391. (c) Nguyen, P.; Gomez-Elipe, P.; Manners, I. Organometallic Polymers with Transition Metals in the Main Chain. Chem. Rev. 1999, 99, 1515-1548.

(13) (a) Miyajima, K.; Nakajima, A.; Yabushita, S.; Knickelbein, M. B.; Kaya, K. Ferromagnetism in One-Dimensional Vanadium-Benzene Sandwich Clusters. J. Am. Chem. Soc. 2004, 126, 13202-13203. (b) Wang, J.; Acioli, P. H.; Jellinek, J. Structure and Magnetism of VnBzn+1 Sandwich Clusters. J. Am. Chem. Soc. 2005, 127, 2812-2813. (c) Brennan, D.E.; Geiger, W.E. Redox properties of small metallocarborane clusters: Electrochemistry of cobalt triple-decker sandwich compounds. J. Am. Chem. Soc. 1979, 101, 339-3400.

(14) (a) Scherer, O. J. Complexes with Substituent-free Acyclic and Cyclic Phosphorus, Arsenic, Antimony, and Bismuth Ligands. Angew. Chem. Int. Ed. Engl. 1990, 29, 1104-1122. (b) Reddy, A. C.; Jemmis, E. D.; Scherer, O. J.; Winter, R.; Heckmann, G.; Wolmershaeuser, G. Electronic structure of triple-decker sandwich complexes with $\mathrm{P}_{6}$ middle rings. Synthesis and $\mathrm{x}$-ray structure determination of $\operatorname{bis}\left(\eta^{5}-1,3\right.$-di-tert-butylcyclopentadienyl $)\left(\mu-\eta^{6}: \eta^{6}\right.$ hexaphosphorin)diniobium. Organometallics 1992, 11, 3894-390. (c) Krauss, H.; Balazs, G.; Bodensteiner, M.; Scheer, M. The potential of a cyclo-As 5 ligand complex in coordination chemistry. Chem. Sci. 2010, 1, 337-342.

(15) Ghosh, S.; Beatty, A. M.; Fehlner, T. P. Synthesis and Characterization of Bicapped Hexagonal Bipyramidal 2,3- $\mathrm{Cl}_{2}-1,8-$ $\{\mathrm{Cp} * \mathrm{Re}\}_{2} \mathrm{~B}_{6} \mathrm{H}_{4}\left[\{\mathrm{Cp} * \mathrm{Re}\}_{2}\left\{\mu-\eta^{6}: \eta^{6}-1,2-\mathrm{B}_{6} \mathrm{H}_{4} \mathrm{Cl}_{2}\right\}, \mathrm{Cp}^{*}=\eta^{5}-\mathrm{C}_{5} \mathrm{Me}_{5}\right]:$ The Missing Link Connecting ( $\mathrm{p}-2)$ Skeletal Electron Pair Hypoelectronic Rhenaboranes and 24-Valence Electron Triple-Decker Complexes. J. Am. Chem. Soc. 2001, 123, 9188-9189.

(16) (a) Li, W. L.; Xie, L.; Jian, T.; Romanescu, C.; Huang, X.; Wang, L. S. Hexagonal Bipyramidal $\left[\mathrm{Ta}_{2} \mathrm{~B}_{6}\right]^{-/ 0}$ Clusters: $\mathrm{B}_{6}$ Rings as Structural Motifs. Angew. Chem., Int. Ed. 2014, 53, 1288-1292. (b) Kawamura, K.; Shang, M.; Wiest, O.; Fehlner, T. P. Synthesis and Structure of $\left\{\eta^{5}-\mathrm{C}_{5} \mathrm{H}_{5} \mathrm{Cr}\right\}_{2}\left\{\mu-\eta^{6}: \eta^{6}-\left(\mu-1,2-\mathrm{C}_{3} \mathrm{H}_{6}-1,2-\mathrm{C}_{2} \mathrm{~B}_{4} \mathrm{H}_{4}\right)\right\}$. An Unusual 24-Electron Triple-Decker Sandwich Complex Containing a Metal-Stabilized, Planar Tetraborabenzene. Inorg. Chem. 1998, 37, 608-609.

(17) Ghosh, S.; Shang, M.; Fehlner, T. P. A Novel Coordinated Inorganic Benzene: Synthesis and Characterization of $\left\{\eta^{5-}\right.$ 
$\left.\mathrm{C}_{5} \mathrm{Me}_{5} \mathrm{Re}\right\}_{2}\left\{\mu-\eta^{6}: \eta^{6}-\mathrm{B}_{4} \mathrm{H}_{4} \mathrm{Co}_{2}(\mathrm{CO})_{5}\right\}$. J. Am. Chem. Soc. 1999, 121, 7451-7452.

(18) Thakur, A.; Chakrahari, K. K. V.; Mondal, B.; Ghosh, S. Novel Triple Decker Sandwich Complex with a Six-Membered $\left[\mathrm{B}_{3} \mathrm{Co}_{3}\left(\mu^{4}-\right.\right.$ Te)] Ring as the Middle Deck. Inorg. Chem. 2013, 52, 2262-2264.

(19) Mondal, B.; Mondal, B.; Pal, K.; Varghese, B.; Ghosh S. An electron-poor di-molybdenum triple-decker with a puckered $\left[\mathrm{B}_{4} \mathrm{Ru}_{2}\right]$ bridging ring is an oblato-closo cluster. Chem. Commun. 2015, 51, 3828-3831.

(20) Mondal, B.; Bhattacharyya, M.; Varghese, B.; Ghosh, S. Hypo-electronic triple-decker sandwich complexes: synthesis and structural characterization of $\left[\left(\mathrm{Cp}^{*} \mathrm{Mo}\right)_{2}\left\{\mu-\eta^{6}: \eta^{6}-\mathrm{B}_{4} \mathrm{H}_{4} \mathrm{E}-\mathrm{Ru}(\mathrm{CO})_{3}\right\}\right]$ $\left(\mathrm{E}=\mathrm{S}, \mathrm{Se}, \mathrm{Te}\right.$ or $\mathrm{Ru}(\mathrm{CO})_{3}$ and $\left.\mathrm{Cp}^{*}=\eta^{5}-\mathrm{C}_{5} \mathrm{Me}_{5}\right)$. Dalton Trans. 2016, 45, 10999-11007.
(21) Mondal, B.; Bag, R.; Roisnel, T.; Ghosh, S. Use of SingleMetal Fragments for Cluster Building: Synthesis, Structure, and Bonding of Heterometallaboranes. Inorg. Chem. 2019, 58, 27442754.

(22) Bag, R.; Saha, S.; Borthakur, R.; Mondal, B.; Roisnel, T.; Dorcet, V.; Halet, J.-F.; Ghosh, S. Synthesis, Structures and Chemistry of the Metallaboranes of Group 4-9 with $\mathrm{M}_{2} \mathrm{~B}_{5}$ Core Having a Cross Cluster M-M Bond. Inorganics 2019, 7, 27-41.

(23) Mondal, B.; Bag, R.; Ghosh, S. Combined Experimental and Theoretical Investigations of Group 6 Dimetallaboranes $\left[(\mathrm{Cp} * \mathrm{M})_{2} \mathrm{~B}_{4} \mathrm{H}_{10}\right](\mathrm{M}=\mathrm{Mo}$ and $\mathrm{W})$ Organometallics 2018, 37, 24192428.

\section{For Table of Contents}

Two new 24-valence electron triple-decker complexes of tungsten bearing a planar and puckered middle deck have been synthesized and structurally characterized (see picture).

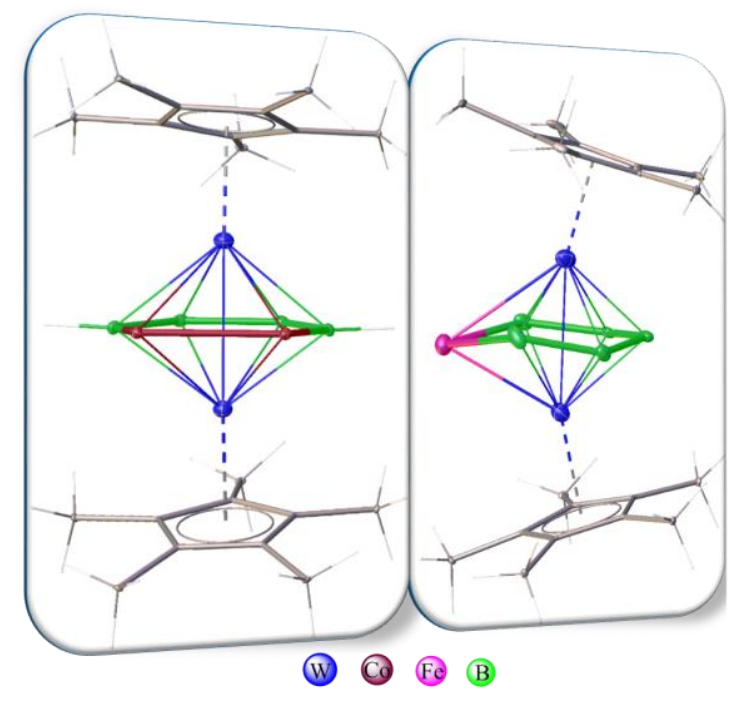

